\title{
Optimalisasi Sektor Pertanian Dalam Rangka Mengatasi Pengangguran Di Sumatera Utara
}

\section{Optimizing the Agricultural Sector to Overcome Unemployment in North Sumatra}

\author{
Rita Herawaty Br Bangun* \\ Fungsional Statistik BPS Provinsi Sumatera Utara \\ Diterima: Agustus 2021 Disetujui: Oktober 2021 Dipublish: Oktober 2021 \\ *Corresponding Email: $\underline{\text { rita.bangun@bps.go.id }}$
}

\begin{abstract}
Abstrak
Sektor pertanian tetap menjadi andalan di masa pandemi Covid-19 di Sumatera Utara. Sektor pertanian berperan penting dalam menopang perekonomian dan penyerapan tenaga kerja di Sumatera Utara. Tujuan dari penelitian ini adalah untuk mengidentifikasi peranan sektor pertanian yang optimal dalam rangka menurunkan tingkat pengangguran di Sumatera Utara. Data yang digunakan adalah data sekunder periode Tahun 2005 sampai 2019. Metode analisis yang digunakan adalah analisis korelasi Pearson. Hasil analisis menunjukkan TPT di wilayah perkotaan dengan laju pertumbuhan sektor pertanian mempunyai hubungan yang tidak signifikan, sedangkan hubungan antara TPT di wilayah perdesaan dan TPT di Provinsi Sumatera Utara mempunyai hubungan yang signifikan dengan laju pertumbuhan sektor pertanian. TPT wilayah perdesaan dan TPT Provinsi Sumatera Utara mempunyai hubungan yang kuat dan negatif dengan pertumbuhan sektor pertanian. Hasil pengujian dengan analisis regresi sederhana menunjukkan pertumbuhan sektor pertanian memiliki pengaruh yang negatif terhadap tingkat pengangguran di wilayah perdesaan dan tingkat pengangguran di Sumatera Utara.
\end{abstract}

Kata Kunci: pengangguran; sektor pertanian

\begin{abstract}
The agricultural sector remains a mainstay during the Covid-19 pandemic in Sumatera Utara. The agricultural sector has an important role in supporting the economy and employment in North Sumatra. The purpose of the study was to identify the optimal role of the agricultural sector in order to reduce the unemployment rate in Sumatera Utara. The data used is secondary data for the period 2005 to 2019. The analytical method used is Pearson Correlation Analysis. The results of the analysis show that TPT in urban areas with the growth rate of the agricultural sector has an insignificant relationship, while the relationship between TPT in rural areas and TPT in North Sumatra Province has a significant relationship with the growth rate of the agricultural sector. TPT in rural areas and TPT in North Sumatra Province have a strong and negative relationship with the growth of the agricultural sector. The test results with simple regression analysis show that the growth of the agricultural sector has a negative effect on the unemployment rate in rural areas and the unemployment rate in North Sumatra.
\end{abstract}

Keywords: agricultural sector; unemployment 


\section{PENDAHULUAN}

Pandemi COVID-19 yang terjadi di seluruh dunia termasuk Indonesia mendorong pemerintah menerapkan kebijakan pembatasan jarak (social distancing) termasuk di Sumatera Utara. Kebijakan tersebut menyebabkan perubahan aktivitas sosial ekonomi masyarakat seperti ditutupnya pusat perbelanjaan, tempat rekreasi dan hiburan serta pembatasan transportasi. Kondisi ini berdampak terhadap pendapatan masyarakat khususnya pekerja. Ngadi et al., (2020) menyebutkan bahwa terdapat 25 juta pekerjaan yang hilang akibat pandemi COVID-19. Kondisi yang sama juga terjadi di Sumatera Utara, awal Mei Tahun 2020 diperkirakan sebanyak 14 ribu orang kehilangan pekerjaan dan potensi tingkat pengangguran di Sumatera Utara akibat COVID-19 diperkirakan mencapai 10 persen (BI, 2020). Peningkatan pengangguran yang terjadi tentu saja akan menghambat proses pembangunan sehingga perlu dilakukan upaya untuk penanganannya. Tingkat pengangguran terbuka (TPT) di Sumatera Utara pada bulan Februari 2020 sebesar 4,73 persen atau turun sebesar 0,83 persen dibandingkan dengan bulan Februari 2019 (BPS, 2020b). Penurunan TPT ini juga diiringi dengan penurunan tingkat pengangguran terbuka di Sumatera Utara selama tiga tahun terakhir cenderung menunjukkan penurunan (BPS, 2020b). Namun, penurunan pengangguran di Provinsi Sumatera Utara masih tergolong masih sangat lambat dan masih di atas angka nasional yang sebesar 5,41 persen (BPS, 2020b). Pandemi COVID-19 juga memberi dampak negatif terhadap perekonomian Sumatera Utara pada triwulan II Tahun 2020 yang mengalami kontraksi sebesar 2,37 persen dibanding triwulan II Tahun 2019 (BPS, 2020c).

Keterpurukan sektor ekonomi ini tidak diikuti oleh sektor pertanian yang masih tetap tumbuh dan mampu bertahan menghadapi krisis akibat pandemi. Badan Pusat Statistik (BPS) menyatakan bahwa sektor pertanian tumbuh sebesar 0,35 persen dan berkontribusi sebesar 21,37 persen pada triwulan II Tahun 2020 (BPS, 2020c). Sektor pertanian juga berperan penting dalam penyerapan angkatan kerja di Sumatera Utara selama 15 tahun terakhir. Sektor pertanian menyerap sekitar 52,68 persen pada Tahun 2005 dan menurun menjadi 35,54 persen pada Tahun 2019 (BPS, 2020a). Menurunnya serapan angkatan kerja menarik untuk dikaji lebih mendalam untuk mengetahui apakah ada hubungannya dengan sektor pertanian secara langsung, meskipun peranan sektor ini masih tetap mendominasi dibandingkan dengan sektor lainnya.

Isbah dan Iyan (2016) menyatakan bahwa sektor pertanian berperan aktif dalam penyerapan tenaga kerja dan perekonomian di Provinsi Riau. Ishak (2018) juga menjelaskan bahwa penyerapan tenaga kerja di Kalimantan Timur dipengaruhi oleh nilai tambah sektor pertanian. Rozi et al., (2011) juga melakukan penelitian tentang peranan sektor pertanian dalam penyerapan tenaga kerja di Provinsi Aceh.

Penetapan Kabupaten Humbang Hasundutan di Provinsi Sumatera Utara sebagai salah satu sebagai lokasi food estate, yang berarti menjadi salah satu lumbung pangan nasional berbasis pertanian, menjadi menarik untuk dikaji secara mendalam mengenai hubungan sektor pertanian dengan tingkat pengangguran. Kajian ini bertujuan untuk mengidentifikasi peranan sektor pertanian yang optimal dalam rangka menurunkan tingkat pengangguran di Sumatera Utara. Pola hubungan antara sektor pertanian dan tingkat pengangguran di Sumatera Utara akan dianalisis secara mendalam dan akan menghasilkan korelasi yang bisa dijadikan acuan dalam perencanaan pembangunan pertanian yang berbasis penciptaan lapangan kerja.

\section{METODE PENELITIAN}

Penelitian ini menggunakan data sekunder yang bersumber dari BPS Provinsi Sumatera Utara. Data yang digunakan adalah data deret waktu selama periode tahun 2005 sampai tahun 2019. Variabel yang digunakan adalah tingkat pengangguran terbuka yang dibedakan menurut 
wilayah perkotaan dan perdesaan serta laju pertumbuhan sektor pertanian di Sumatera Utara. Metode analisis yang digunakan adalah analisis korelasi Pearson yang bertujuan untuk mengidentifikasi keeratan hubungan antara dua variabel dan mengetahui arah hubungan yang terjadi (Kuncoro, 2017; Sihombing \& Bangun, 2019). Korelasi negatif ditunjukkan dengan koefisien korelasi yang bernilai negatif begitu juga sebaliknya korelasi positif ditunjukkan dengan koefisien korelasi yang bernilai positif. Interpretasi terhadap koefisien korelasi ditunjukkan pada Tabel 1.

Tabel 1. Interpretasi Koefisien Korelasi

\begin{tabular}{c|c}
\hline Interval Koefisien & Tingkat Hubungan \\
\hline $0,80-1$ & Sangat kuat \\
\hline $0,60-0,79$ & Kuat \\
\hline $0,40-0,59$ & Cukup kuat \\
\hline $0,20-0,39$ & Rendah \\
\hline $0,00-0,19$ & Sangat rendah \\
\hline
\end{tabular}

Sumber: Kuncoro, 2017

Model korelasi Pearson dalam kajian ini dinyatakan sebagai berikut:

$$
\mathrm{r}=\frac{n\left(\sum \mathrm{xiyi}\right)-\left(\sum \mathrm{xi}\right)\left(\sum \mathrm{yi}\right)}{\sqrt{\left\{\left(n \sum x i^{2}\right)-\left(\sum x i\right)^{2}\right\}\left\{\left(n \sum y i^{2}\right)-\left(\sum y i\right)^{2}\right\}}}
$$

Dimana:

r adalah korelasi Pearson yang nilainya antara -1 dan 1 ,

$\mathrm{y}_{\mathrm{i}}$ adalah tingkat pengangguran terbuka (TPT) Sumatera Utara dan TPT menurut wilayah, sedangkan

$\mathrm{x}_{\mathrm{i}}$ adalah laju pertumbuhan sektor pertanian.

Pengujian lebih lanjut dilakukan dengan uji regresi untuk variabel yang teridentifikasi signifikan mempunyai hubungan. Model regresi dinyatakan sebagai berikut:

$$
\mathrm{y}_{\mathrm{t}}=\mathrm{a}+\mathrm{b} \mathrm{x}_{\mathrm{t}}+\mathrm{e}
$$

Y merupakan variabel tingkat pengangguran dan

$\mathrm{x}$ merupakan variabel laju pertumbuhan pertanian.

\section{HASIL DAN PEMBAHASAN}

\section{Kondisi Ketenagakerjaan di Sumatera Utara}

Tingkat partisipasi angkatan kerja (TPAK) dan tingkat pengangguran terbuka (TPT) merupakan indikator yang sering digunakan oleh pemerintah daerah untuk menilai kinerja di bidang ketenagakerjaan. TPAK menunjukkan besarnya penduduk usia kerja (15 tahun ke atas) yang aktif secara ekonomi di suatu wilayah. Semakin tinggi nilai TPAK menunjukkan semakin banyak penduduk usia kerja yang berpartisipasi aktif dalam perekonomian. TPAK di Sumatera Utara pada bulan Februari 2020 sebesar 72 persen, turun 2,57 persen dibanding TPAK Februari Tahun 2019 yang sebesar 74,57 persen (BPS, 2020b). TPAK di Sumatera Utara selama kurun waktu Tahun 2005 sampai Tahun 2019 menunjukkan kecenderungan berfluktuatif (Tabel 2). TPAK terendah pada Tahun 2008 sebesar 65,99 persen artinya dari 100 penduduk usia kerja terdapat sekitar 66 orang yang aktif dalam kegiatan ekonomi sedangkan TPAK tertinggi pada Tahun 2011 sebesar 72,09 persen. Fluktuasi partispasi angkatan kerja dapat dipengaruhi oleh beberapa faktor 
diantaranya perubahan jumlah angkatan kerja, tingkat upah, tingkat pendidikan dan pertumbuhan ekonomi (Murialti \& Romanda, 2020; Noveda et al., 2015).

Tingkat pengangguran terbuka (TPT) digunakan untuk mengukur tingkat penawaran tenaga kerja yang tidak terserap oleh pasar tenaga kerja. TPT di Sumatera Utara pada bulan Februari 2020 sebesar 4,73 persen atau turun sebesar 0,83 persen dibandingkan dengan bulan Februari 2019 (BPS, 2020b). Selama 15 tahun terakhir TPT Sumatera Utara cenderung menunjukkan penurunan, namun penurunan yang terjadi masih tergolong lambat (Tabel 2). TPT Sumatera Utara juga masih di atas angka nasional yang sebesar 5,41 persen (BPS, 2020b). Tingginya tingkat pengangguran akan menjadi hambatan dalam proses pembangunan. Akhmad (2020) menjelaskan bahwa angka pengangguran yang tinggi menyebabkan banyak masyarakat yang tidak memperoleh pekerjaan sehingga mempengaruhi kesejahteraan dan keamanan masyarakat.

Dilihat berdasarkan tempat tinggal, angka pengangguran di wilayah perkotaan cenderung lebih tinggi dibanding di pedesaan (Tabel 2). TPT di perkotaan sebesar 6,75 persen sedangkan TPT di pedesaan sebesar 2,33 persen (BPS, 2020b). Pembangunan yang tidak merata antara desa dan kota menyebabkan terjadinya arus migrasi ke wilayah perkotaan terutama untuk mencari pekerjaan. Faktor pendukung lainnya adalah upah di perkotaan lebih besar dibandingkan dengan upah di daerah pedesaan, sehingga mendorong masyarakat pedesaan melakukan migrasi untuk mendapatkan pekerjaan yang jauh lebih baik di wilayah perkotaan. Nagib \& Ngadi (2008) menjelaskan bahwa pendapatan pada sektor perdagangan, jasa, dan industri yang mendominasi pekerjaan di perkotaan lebih tinggi dibandingkan dengan upah di sektor pertanian sehingga mendorong penduduk desa bermigrasi ke kota.

Tabel 2. Tingkat Pengangguran Terbuka (TPT) menurut Daerah Tempat Tinggal dan Tingkat Partisipasi Angkatan Kerja (TPAK) Di Sumatera Utara, 2005-2019

\begin{tabular}{|c|c|c|c|c|}
\hline \multirow[b]{2}{*}{ Tahun } & \multicolumn{3}{|c|}{ Tingkat Pengangguran Terbuka (TPT) (Persen) } & \multirow{2}{*}{$\begin{array}{c}\text { Tingkat } \\
\text { Partisipasi } \\
\text { Angkatan Kerja } \\
\text { (TPAK) (Persen) }\end{array}$} \\
\hline & TPT Perkotaan & TPT Pedesaan & $\begin{array}{c}\text { TPT Sumatera } \\
\text { Utara }\end{array}$ & \\
\hline 2005 & 14,56 & 9,99 & 11,9 & 71,94 \\
\hline 2006 & 13,3 & 10,13 & 11,51 & 66,90 \\
\hline 2007 & 12,02 & 8,74 & 10,1 & 67,49 \\
\hline 2008 & 11,46 & 7,35 & 9,1 & 68,33 \\
\hline 2009 & 12,2 & 5,69 & 8,45 & 69,14 \\
\hline 2010 & 10,84 & 5,1 & 7,43 & 69,51 \\
\hline 2011 & 9,19 & 3,96 & 6,37 & 72,09 \\
\hline 2012 & 9,19 & 3,65 & 6,2 & 69,41 \\
\hline 2013 & 8,67 & 3,53 & 6,53 & 70,67 \\
\hline 2014 & 7,93 & 4,68 & 6,23 & 67,07 \\
\hline 2015 & 8,81 & 4,61 & 6,71 & 67,28 \\
\hline 2016 & 7,55 & 4,17 & 5,84 & 65,99 \\
\hline 2017 & 7,37 & 3,67 & 5,6 & 68,88 \\
\hline 2018 & 7,03 & 3,92 & 5,56 & 71,82 \\
\hline 2019 & 8,67 & 3,53 & 6,53 & 70,19 \\
\hline
\end{tabular}

Sumber: BPS Provinsi Sumatera Utara, 2005-2019

\section{Pengangguran dan Pertumbuhan Sektor Pertanian}

Tabel 3 menunjukkan bahwa TPT di wilayah perkotaan dengan laju pertumbuhan sektor pertanian mempunyai hubungan yang tidak signifikan, sedangkan hubungan antara TPT di wilayah 
pedesaan dan TPT di Provinsi Sumatera Utara mempunyai hubungan yang signifikan dengan laju pertumbuhan sektor pertanian. TPT wilayah pedesaan dan TPT Provinsi Sumatera Utara mempunyai hubungan yang kuat dan negatif dengan pertumbuhan sektor pertanian. Hasil kajian ini mendukung penelitian yang dilakukan oleh Fitri \& Satrio (2019) yang menyimpulkan bahwa terdapat hubungan kausalitas satu arah antara pertumbuhan sektor pertanian dengan tingkat pengangguran di wilayah perdesaan dan tingkat pengangguran nasional. Penyerapan angkatan kerja di sektor pertanian relatif lebih besar dibandingkan sektor lainnya khususnya di wilayah perdesaan karena sektor ini masih menjadi sumber penghasilan bagi penduduk (Harfina, 2009).

Tabel 3. Hasil Uji Korelasi Pearson

\begin{tabular}{l|c|c}
\hline Variabel & Pearson Correlation & $p$-value \\
\hline TPT perkotaan dan Pertumbuhan Sektor Pertanian & $-0,48$ & 0,067 \\
\hline TPT perdesaan dan Pertumbuhan Sektor Pertanian & $-0,60$ & 0,018 \\
\hline $\begin{array}{l}\text { TPT Sumatera Utara dan Pertumbuhan Sektor } \\
\text { Pertanian }\end{array}$ & $-0,61$ & 0,014 \\
\hline
\end{tabular}

Sumber: Hasil Pengolahan Data Sekunder, 2021

Hasil pengujian dengan analisis regresi sederhana pada Tabel 4, pertumbuhan sektor pertanian memiliki pengaruh yang negatif terhadap tingkat pengangguran di wilayah perdesaan dan tingkat pengangguran di Sumatera Utara. Kenaikan pertumbuhan sektor pertanian sebesar 1 persen akan menurunkan pengangguran di wilayah perdesaan sebesar 1,57 persen. Kenaikan pertumbuhan sektor pertanian akan menurunkan tingkat pengangguran di Sumatera Utara sebesar 1,36 persen.

Tabel 4. Hasil Uji Regrsi

\begin{tabular}{l|c|c|c}
\hline \multicolumn{1}{c|}{ Variabel } & $R^{2}$ & $t$-statistik & $p$-value \\
\hline $\begin{array}{l}\text { TPT Pedesaan dan Pertumbuhan Sektor } \\
\text { Pertanian }\end{array}$ & 0,381 & $-1,5745$ & 0,0142 \\
\hline $\begin{array}{l}\text { TPT Sumatera Utara dan Pertumbuhan } \\
\text { Sektor Pertanian }\end{array}$ & 0,359 & $-1,3675$ & 0,01825 \\
\hline
\end{tabular}

Sumber: Hasil pengolahan data sekunder, 2021

Hasil kajian ini menunjukkan bahwa perubahan yang terjadi pada sektor pertanian akan mempengaruhi tingkat pengangguran di wilayah perdesaan dan Sumatera Utara. Ishak (2018) menjelaskan bahwa sektor pertanian memiliki pengaruh yang signifikan dalam penyerapan angkatan kerja, pertumbuhan sektor pertanian yang cepat akan menurunkan tingkat pengangguran. Adriani \& Wildayana (2015) juga menjelaskan bahwa sektor pertanian memiliki linkage terhadap sektor lain di bagian hulu dan hilir karena kemampuan sektor pertanian berpengaruh terhadap penyerapan tenaga kerja sektktor pertanian dan non pertanian. Sektor pertanian juga secara berkesinambung mampu menyerap angkatan kerja dalam jangka panjang dibandingkan sektor lainnya dan dalam proses produksinya sektor pertanian mengandalkan faktor produksi yang berasal dari dalam negeri agar lebih stabil menghadapi gejolak ekonomi (Syam \& Noekman, 2003). Upaya yang dapat dilakukan dalam mendorong peningkatan laju pertumbuhan sektor sebagai salah satu strategi dalam menurunkan tingkat pengangguran antara lain melakukan optimalisasi di sektor pertanian terutama pembangunan food estate sehingga produktivitas pertanian, pembangunan infrastruktur dan kemudahan akses menjadi lebih meningkat. Pembangunan food estate menjadi salah satu strategi dalam meningkatkan daya saing di bidang ekonomi untuk menyerap lebih banyak angkatan kerja dari sektor pertanian. 


\section{SIMPULAN}

Pertumbuhan sektor pertanian memberikan dampak terhadap pengurangan tingkat pengangguran di wilayah perdesaan dan Provinsi Sumatera Utara. Optimalisasi sektor pertanian menjadi salah satu strategi dalam menurunkan tingkat pengangguran di Sumatera Utara dengan pembangunan food estate.

\section{DAFTAR PUSTAKA}

Adriani, D., \& Wildayana, E. (2015). Integrasi Pertumbuhan Ekonomi Dan Penciptaan Kesempatan Kerja Sektor Pertanian Di Indonesia. Sosiohumaniora, $\quad 17(3), \quad 269$. Https://Doi.Org/10.24198/Sosiohumaniora.V17i3.8381

Akhmad. (2020). Hubungan Kausalitas Kemiskinan, Tingkat Pengangguran, Dan Pertumbuhan Ekonomi Di Provinsi Sulawesi Selatan. Jurnal Ekonomi Balance, 16(1), 13-23. Https://Doi.Org/10.26618/Jeb.V16i1.3505

BI. (2020). Laporan Perekonomian Provinsi Sumatera Utara Mei 2020. Medan: Bank Indonesia Perwakilan Provinsi Sumatera Utara.

BPS. (2020a). Keadaan Angkatan Kerja Di Provinsi Sumatera Utara. Medan: Badan Pusat Statistik Provinsi Sumatera Utara.

BPS. (2020b). Keadaan Ketenagakerjaan Sumatera Utara Februari 2020. Medan.Badan Pusat Statistik

BPS. (2020c). PERTUMBUHAN EKONOMI SUMATERA UTARA TRIWULAN II-2020. Retrieved From Https://Sumut.Bps.Go.Id/Pressrelease/2020/05/05/726/Ekonomi-Sumatera-Utara-Triwulan-I2020-Tumbuh-4-65-Persen.Html

Fitri, I. F., \& Satrio, I. (2019). Analisis Hubungan Pertumbuhan Pertanian Terhadap Pengangguran Di Indonesia. Jurnal Sosial Ekonomi Dan Kebijakan Pertanian, 8(1), 1-6. Https://Doi.Org/Http://Dx.Doi.Org/10.21107/Agriekonomika.V6i1.1895

Harfina, D. (2009). Faktor-Faktor Yang Mempengaruhi Pengangguran Terselubung Perdesaan Jawa Tengah (Analisis Data Sakernas 2007). Jurnal Kependudukan Indonesia, I4(1), 15-32.

Isbah, U., \& Iyan, R. Y. (2016). Analisis Peran Sektor Dalam Perekonomian Dan Kesempatan Kerja Pertanian Di Provinsi Riau. Jurnal Sosial Ekonomi Pembangunan, 7(19), 45-54.

Ishak, A. F. (2018). Pengaruh Nilai Tambah Sektor Pertanian Terhadap Penyerapan Tenaga Kerja Di Kalimantan Timur. Jurnal Agribisnis Indonesia, 1(1), 1-8. Https://Doi.Org/10.29244/Jai.2013.1.1.1-8

Kuncoro, A. (2017). Korelasi Penguasaan Kosakata Dengan Keterampilan Berbicara Siswa Dalam Bahasa Inggris. SAP (Susunan Artikel Pendidikan), 1(3), 302-311. Https://Doi.Org/10.30998/Sap.V1i3.1547

Murialti, N., \& Romanda, R. (2020). Analisis Tingkat Partisipasi Angkatan Kerja Di Propinsi Bengkulu (20102019) Analysis. Jurnal Akuntansi \& Ekonomika, 10(1), 100-118.

Nagib, L., \& Ngadi. (2008). Challenges Of Unemployment In Indonesia: Trends, Issues And Policies. Jurnal Kependudukan Indonesia, $3(2), \quad 1-28 . \quad$ Retrieved Http://Ejurnal.Kependudukan.Lipi.Go.Id/Index.Php/Jki/Article/View/167

Ngadi, Meilianna, R., \& Purba, Y. A. (2020). Dampak Pandemi Covid-19 Terhadap Phk Dan Pendapatan Pekerja Di Indonesia ( The Impact Of Covid-19 On Worker Layoffs And Income In Indonesia ). Jurnal Kependuduka, 1(1), 43-48.

Noveda, D., Aimon, H., \& Syofyan, E. (2015). Analisis Faktor-Faktor Yang Mempengaruhi Penawaran Dan Permintaantenaga Kerja Di Sumatera Barat. Jurnal Kajian Ekonomi, 3(6), 103191.

Rozi, T. F., Sofyan, \& Marsudi, E. (2011). Peranan Sektor Pertanian Dalam Penyerapan Tenaga Kerja Di Provinsi Aceh. Jurnal Ilmiah Mahsiswa Pertanian Unsyiah, 2(2), 59-66.

Sihombing, A. O., \& Bangun, R. H. (2019). Analisis Korelasi Sektor Pertanian Terhadap Tingkat Kemiskinan Di Provinsi Sumatera Utara. Jurnal Agrica, 12(1), 17-24. Https://Doi.Org/10.31289/Agrica.V12i1.2220

Syam, A., \& Noekman, K. M. (2003). Kontribusi Sektor Pertanian Dalam Penyediaan Lapangan Kerja Dan Perbandingannya Dengan Sektor-Sektor Lain. SOCA, 3(1), 74-82. 